\title{
Membangun Aplikasi Sms Gateway Sebagai Media Informasi Harga Barang (Studi Kasus Toko Margo Rukun Nganjuk)
}

\author{
Gianto Widodo ${ }^{[1]}$,Fatchurrochman ${ }^{[2]}$ \\ ${ }^{[1]}$ Mahasiswa Pasca Sarjana Teknik Elektro Universitas Brawijaya \\ ${ }^{[2]}$ Dosen Teknik Informatika UIN Maulana Malik Ibrahim Malang
}

\begin{abstract}
Abstrak-Persaingan di dunia perdagangan saat ini semakin ketat sehingga membuat para pemilik usaha harus mempunyai strategi jitu untuk bisa mengembangkan usahanya, salah satu strategi yang bisa digunakan adalah melakukan komunikasi langsung terhadap pelanggan, karena dengan adanya komunikasi tersebut, hubungan antara pemilik usaha dengan konsumen bisa semakin dekat. Salah satu media penyampaian informasi yang cepat, murah, mudah dan saat ini cukup populer dikalangan masyarakat adalah melalui SMS. Toko Margo Rukun merupakan sebuah usaha perdagangan yang mempunyai lebih dari 100 pelanggan setiap harinya, sebagai usaha yang mempunyai banyak pelanggan tentunya peningkatan kualitas pelayanan harus dilakukan agar pelanggan merasa nyaman, salah satunya dengan membangun sebuah sarana yang bisa memberikan informasi secara langsung kepada pelanggan, terutama mengenai informasi harga barang. Penelitian ini bertujuan membangun sebuah aplikasi SMS Gateway untuk mengetahui informasi harga barang di toko margo rukun. Aplikasi ini memanfaatkan fitur layanan SMS sebagai media informasi kepada pelanggan yang ingin mengetahui harga barang tertentu berdasarkan dengan format SMS yang sudah ditentukan. Sebelum melakukan request harga barang, pelanggan harus melakukan pendaftaran terlebih dahulu baru bisa request harga barang yang diinginkan. Aplikasi SMS Gateway bisa berjalan sesuai dengan harapan dengan tingkat respon terhadap request yang masuk hingga 100\% untuk ujicoba 3 SMS request dan $80 \%$ untuk 5 SMS.
\end{abstract}

Kata Kunci : SMS,SMS Gateway,SMS Request, Harga Barang

\section{PENDAHULUAN}

Dahulu SMS hanya digunakan sebatas untuk pengiriman pesan atau informasi yang bersifat pribadi, kini SMS sudah digunakan untuk berbagai hal.Misal untuk kuis berhadiah pada acara stasiun televisibahkan kegiatan sosial seperti penggalangan dana untuk korban bencana alam sekarang ini juga menggunakan SMS. Untuk dunia bisnis khususnya perbankan, SMS kini dipakai untuk memberikan informasi dan sarana transaksi nasabah sehingga mereka bisa melakukan transaksi dimanapun dan kapanpun dengan menggunakan SMS.

Hasil penelitian lain yang membahas mengenai SMS Gateway diantaranya padaTahun $2006 \quad$ Saranphong Pramsanedkkmengemukakan, dengan menggunakan SMS Gateway,DataSource, seperti kelas, Informasi pendaftaran, Pengumuman Universitas, dan Kesempatan magang serta informasi berharga lain dapat diakses oleh siswa kapan saja dengan menempatkan database yang terhubung dengan server SMS, sedangkan perangkat lunak bisa dikembangkan dengan Bahasa Java, VB atau orang lain yang mempunyai kemampuan menghubungkan ponsel dengan port[1]. Kemudian Sunardi dkk pada tahun 2009 mengemukakan bahwa SMS gateway adalah suatu sistem yang menjembatani antara handphone dengan sistem yang menjadi server dengan SMS sebagai informasinya kemudian untuk menjalankan aplikasi SMS gateway diperlukan komponen-komponen PC, Handphone, kabel data dan MobileFbus[2]. Tahun 2008Suryani menyatakandengan menggunakan sistem yang ia kembangkan siswa dapat mengakses informasi dari sekolah tanpa harus datang langsung kesekolah, cukup hanya mengirimkan SMS yang prosedurnya sama seperti dengan mengirimkan SMS biasa, tetapi format SMSnya yang ditentukan oleh sistem. Jadi siswa dapat mengakses informasi dari sekolah kapan saja dan dimana saja [3].Sunardi dkk hanya membangun sebuah aplikasi SMS Gateway tanpa menerapkan aplikasi tersebut untuk apa, sehingga dilihat dari segi manfaat jelas kurang. Sementara itu Suryani membangun sistem lebih kompleks tetapi sistem yang dibangun hanya menggunakan 1 buah handphone sehingga sangat mungkin terjadi tabrakan. 
Perangkat yang digunakan untuk menerima dan mengirim dalam penelitian ini menggunakan dua buah handphone, sehingga traffic SMS yang masuk dan yang keluar ditangani oleh dua buah handphone sehingga memperkecil kemungkinan tabrakan.

Tujuan penelitian ini adalah membangun

aplikasi berbasis SMS sebagai media informasi harga barang toko margo rukun nganjuk kepada pelanggan. Sistem ini dapat melayani permintaan informasi harga secara langsung lewat SMS berdasarkan apa yang diinginkan oleh pelanggan sesuai dengan format yang telah ditetapkan.

\section{METODE}

Penelitian ini merupakan pengembangan aplikasi atau perangkat lunak, adapun metodologi yang digunakan dalam pengembangan aplikasi dalam penelitian ini adalah sebagai berikut :

A. Analisis Data

Data yang digunakan dalam penelitian ini menggunakan sampel data sekunder barang yang mewakili keadaan yang sebenarnya, data barang yang digunakan dalam penelitian ini bisa dilihat di tabel 1 .

Tabel 1 .Sampel Data Barang Di Toko Margo Rukun

\begin{tabular}{|l|l|l|l|l|}
\hline $\begin{array}{l}\text { Nm } \\
\text { Barang }\end{array}$ & $\begin{array}{l}\text { Vari } \\
\text { an }\end{array}$ & $\begin{array}{l}\text { Ukur } \\
\text { an }\end{array}$ & $\begin{array}{l}\text { Har } \\
\text { ga }\end{array}$ & $\begin{array}{l}\text { Sto } \\
\text { k }\end{array}$ \\
\hline Rinso & $\begin{array}{l}\text { Molt } \\
\text { o }\end{array}$ & $1 \mathrm{Kg}$ & $\begin{array}{l}15.5 \\
00\end{array}$ & 200 \\
\hline Rinso & $\begin{array}{l}\text { Warn } \\
\text { a }\end{array}$ & $1 \mathrm{Kg}$ & $\begin{array}{l}15.5 \\
00\end{array}$ & 200 \\
\hline Emeron & Botol & $50 \mathrm{ml}$ & $\begin{array}{l}2.00 \\
0\end{array}$ & 150 \\
\hline Emeron & Botol & $100 \mathrm{ml}$ & $\begin{array}{l}3.50 \\
0\end{array}$ & 100 \\
\hline $\begin{array}{l}\text { Pepsod } \\
\text { ent }\end{array}$ & $\begin{array}{l}\text { Herb } \\
\text { al }\end{array}$ & Besar & $\begin{array}{l}20.0 \\
00\end{array}$ & 50 \\
\hline
\end{tabular}

Dalam tabel 1 nampak data beberapa barang yang dipakai dalam ujicoba, nama barang pada kolom Nm Barang merupakan sampeldata asli yang belum dilakukan proses normalisasi, sementara itu angka yang tertera pada kolom Stok adalah jumlah dari barang yang digunakan pada penelitian, Stok pada kolom tabel 1 menggunakan satuan biji.

B. PerancanganSistem

- Blok Diagram
Aplikasi yang dibangun akan berjalan sesuai dengan gambaran blok diagram yang tertera pada gambar 1 .

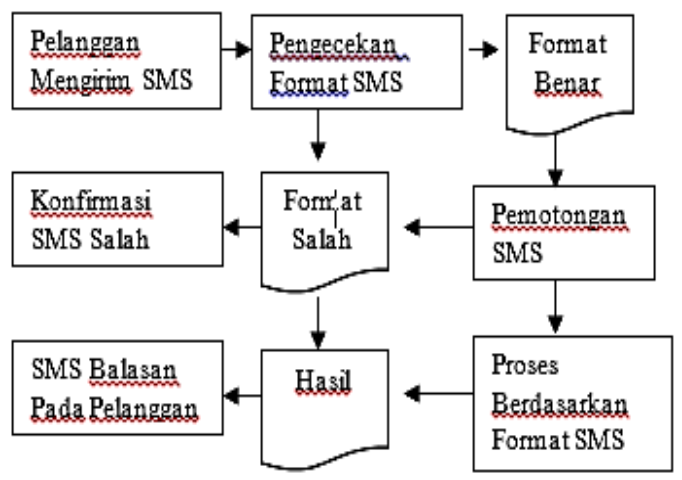

Gambar 1. Blok Diagram Aplikasi.

Blok diagram ini menunjukkan proses berjalannya aplikasi yaitu mulai dari pelanggan mengirimkan SMS, kemudian sistem melakukan pengecekan format SMS, jika format SMS salah maka dikirimkan informasi jika SMS salah, jika format SMS benar maka dilakukan proses pemotorngan SMS menjadi kata yang digunakan untuk parameter SMS balasan kepada pelanggan.

- Usecase Diagram

Usecase diagram memperlihatkan siapa saja yang terlibat didalam system yang dibangun. Diagram ini bisa dilihat digambar 2 .

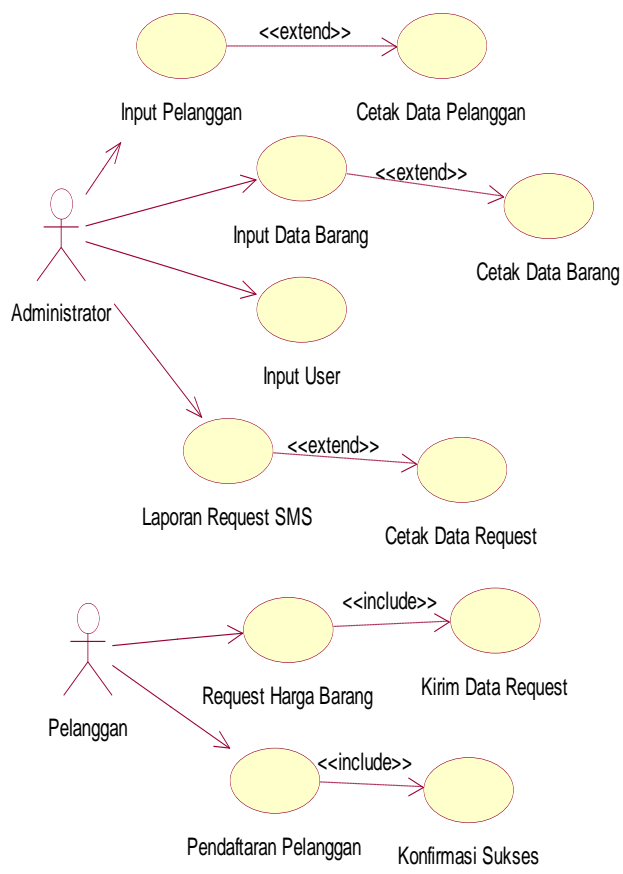

Gambar 2. Usecase diagram. 
Menggambarkan user yang terlibat didalam sistem serta proses yang dijalankan.

Usecase diagram yang pada gambar 2 memperlihatkan user yang terlibat didalam aplikasi. Ada dua user pada aplikasi yaitu administrator dan pelanggan. Setiap user mempunyai aktifitas berbeda, adapun aktifitas tersebut adalah :

1. Administrator bisa melakukan input data pelanggan, input data barang, input user,serta melihat laporan data SMS request yang masuk. Selain melakukan proses tersebut useradministrator juga bisa melakukan proses cetak data pelanggan, cetak data barang serta melakukan cetak data laporan request SMS yang masuk.

2. Pelanggan mempunyaiaktifitas melakukan request harga barang dan melakukan pendaftaran. Proses yang terjadi adalah seorang pelanggan mengirimkan SMS dengan format SMS yang telah ditentukan sebelumnya, diamana SMS yang dikirimkan pelanggan bisa berupa SMS pendaftaran atau juga SMS request informasi harga barang.

- Perancangan Format SMS

Format SMS yang digunakan sebagai acuan pengiriman SMS oleh pelanggan seperti terdapat pada tabel 2 .

Tabel 2 .Format SMS sekaligus fungsi dari format SMS yang dibuat.

\begin{tabular}{|l|l|l|}
\hline No & Format SMS & Fungsi \\
\hline 1 & help & $\begin{array}{l}\text { Untuk bantuan atau } \\
\text { info cara pakai } \\
\text { layanan SMS } \\
\text { pelanggan }\end{array}$ \\
\hline 2 & $\begin{array}{l}\text { inf\#merek } \\
\text { inf\#merek\#varian } \\
\text { inf\#merek\#varian\#u } \\
\text { kuran }\end{array}$ & $\begin{array}{l}\text { Format SMS untuk } \\
\text { informasibarang } \\
\text { berdasarkan merek } \\
\text { dan besifikasi barang } \\
\text { spesi satumerek } \\
\text { pada } \\
\text { tersebut. }\end{array}$ \\
\hline 3 & $\begin{array}{l}\text { mrk\#merek_1 } \\
\text { mrk\#merek_1\#mere } \\
\text { k_2 } \\
\text { mrk\#merek_1\#mere } \\
\text { k_2 merek_3 }\end{array}$ & $\begin{array}{l}\text { Format SMS untuk } \\
\text { informasi barang } \\
\text { berdasarkan } \\
\text { beberapa } \\
\text { merek barang pada } \\
\text { hal in } \\
\text { maksimal tiga } \\
\text { merek barang }\end{array}$ \\
\hline 4 & $\begin{array}{l}\text { Reg\#nama\#alamat\#e } \\
\text { mail }\end{array}$ & $\begin{array}{l}\text { Format SMS } \\
\text { pendaftaran } \\
\text { calonpelanggan }\end{array}$ \\
\hline
\end{tabular}

Tabel 2 memperlihatkan desain dari format SMS yang nantinya digunakan dalam aplikasi. Kolom Format SMS memperlihatkanstruktur SMS yang digunakan acuan oleh aplikasi dalam merespon terhadap SMS yang dikirimkan oleh pelanggan. Sementara itu kolom Fungsi pada tabel 2 memperlihatkan informasi keterangan dari kegunaan Format SMS yang tertulis pada kolom Format SMS.

\section{- Desain Proses}

Gambaran dari proses SMS request pada aplikasi yang dibangun nampak seperti diagram Flowchart yang tertera pada gambar 3.

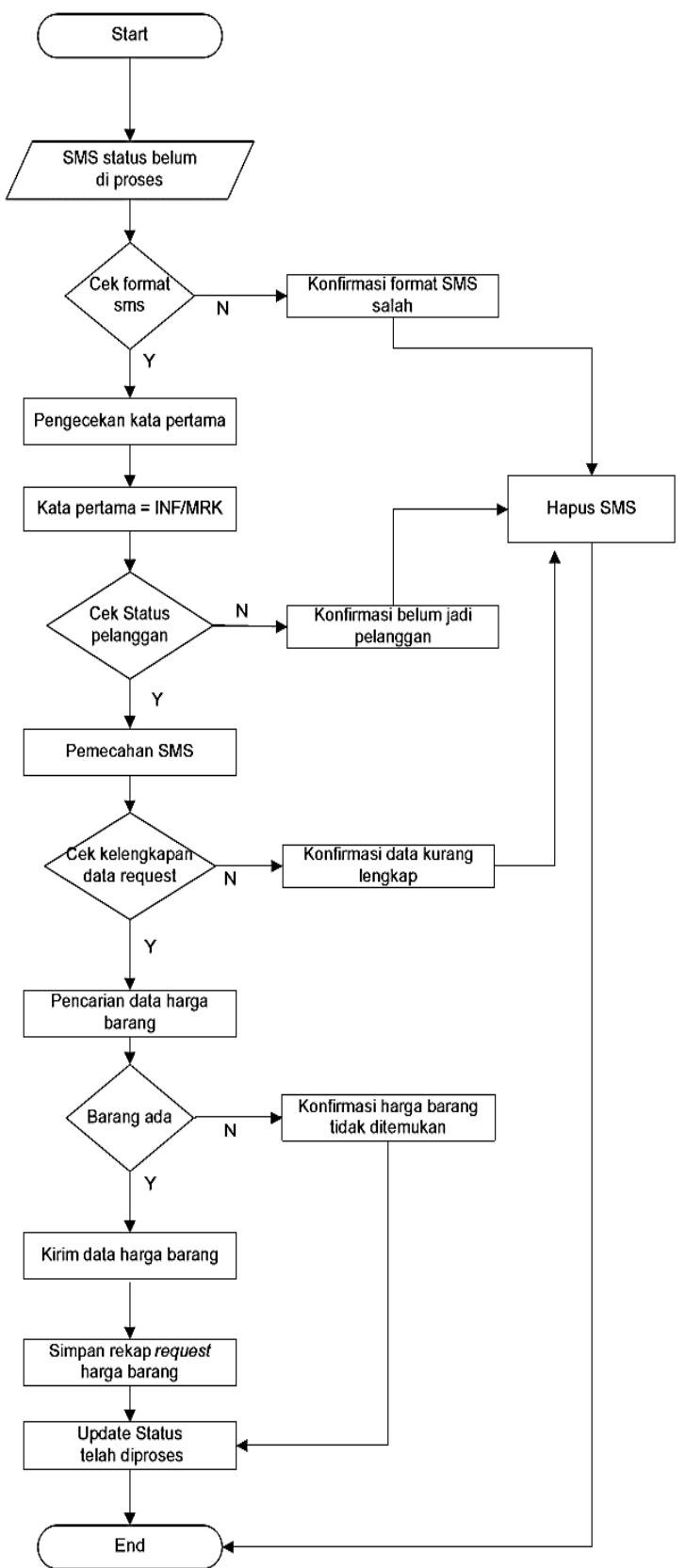

Gambar 3. Flowchart proses request harga barang. 
SMS yang masuk akan dimasukkan kedalam tabel SMS masuk dengan status belum diproses. Kemudian sistem akan melihat format SMS, jika SMS salah maka dikirimkan konfirmasi SMS salah dan SMS dihapus. Jika Benar maka sistem akan melihat apakah SMS sesuai dengan format, jika benar maka dilakukan tahap selanjutnya hingga proses pencarian barang sesuai dengan format requestnya dan status SMS masuk diubah menjadi selesai diproses.

\section{Pembuatan Perangkat Lunak}

Setelah dilakukan perancangan maka dilanjutkan dengan proses pembuatan perangkat lunak.

Aplikasi ini dibangun menggunakan Bahasa pemrograman Java dengan tahapan berikut ini :

- Pembuatan Server SMS Gateway

Pada tahap ini dibuat dua buah library SMS Gateway dengan nama Gianto.jar dan Gianto2.jar yang merupakan hasil rekonstruksi dari kode library Smitdev[4].

Library pertama yaitu Gianto.jar digunakan untuk menangani proses konektivitas antara server dengan handphone penerima, sementara itu Gianto2.jar digunakan untuk menangani proses konektivitas antara server dengan handphone pengirim.

- $\quad$ Proses Identifikasi format SMS masuk

Tahap ini adalah pembuatan kode untuk memeriksa format SMS yang masuk ke server. Format yang sesuai akan dijadikan patokan proses selanjutnya.

Format SMS yang digunakan Acuan pada proses ini adalah format SMS yang telah dijelaskan pada tabel 2 .

- Pemecahan SMS RequestHarga Barang

Pemecahan SMS ini dilakukan untuk mengambil informasi barang yang direquest oleh pelanggan.Pada tahap ini dilakukan proses pemecahan terhadap SMS yang masuk untuk mengetahui jenis informasi barang apa yang diinginkan oleh pelanggan, adapun acuan yang digunakan pada proses pemecahan SMS yang masuk ini adalah format SMS yang terdapat pada tabel 2.

Pada tahap ini akan didapatkan data barang yang akan dikirimkan kepada pelanggan sebagai SMS balasan berdasarkan dengan nama barang yang dikirimkan.

\section{HASIL DAN ANALISA}

Setelah dilakukan proses perancangan dan pembuatan perangkat lunak, selanjutnya dilakukan proses ujicoba sekaligus analisa hasil.

1. Ujicoba Aplikasi

a. Konfigurasi Perangkat

Untuk ujicobadipakai dua buah perangkat handphone yang mendukung Hyper Terminal atau AT Command[4]. Handphone pertama menggunakan jenis Handphone Siemens M55 yang berfungsi sebagai server penerima SMS, sementara handphone kedua menggunakan jenis Siemens C60 yang digunakan untuk server pengirim SMS. Konfigurasi Handphone disusun seperti diagram yang nampak pada gambar 7 .

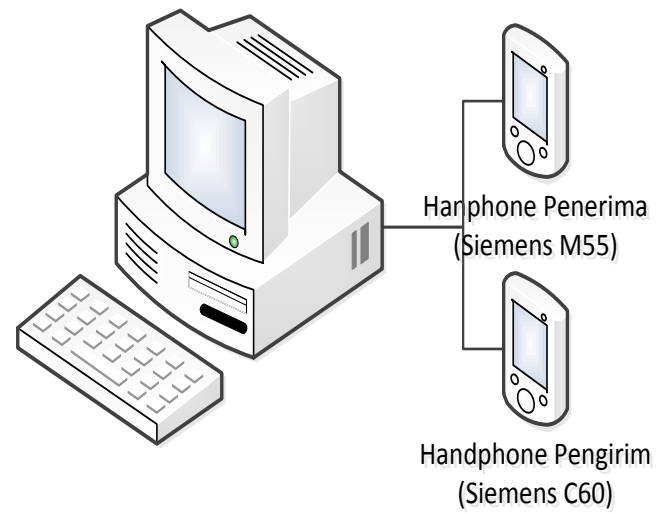

Gambar 7. Konfigurasi Handphone yang digunakan pada ujicoba aplikasi.

Handphone pertama yaitu jenis siemens M55 digunakan sebagai penerima, sedangkan Handphone kedua bertipe Siemens C60 digunakan sebagai pengirim.

b. Fungsional Testing

Setelah dipastikan perangkat sudah terhubung dengan baik, selanjutnya dilakukan proses testing untuk mengetahui apakah aplikasi sudah berjalan sesuai dengan target. Tahap ini dilakukan dengan skema ujicoba berikut ini.

- $\quad$ Fungsi ResponTerhadap SMS Request

Uji coba terhadap fungsi yang menanganipemrosesan terhadap SMS request harga barang dilakukan dengan mengirimkan 1 SMSke server. Format SMS yang dikirimkan bisa dilihat pada gambar 8.(a). Sementara untuk hasil atau respon dari server bisa dilihat pada gambar 8.(b). 


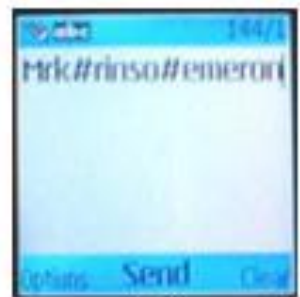

(a)

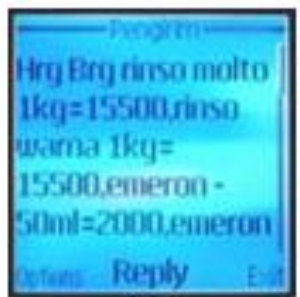

(b)
Gambar 8. (a) SMS ujicoba yang dikirimkan keserver, (b) SMS respon yang dikirimkan oleh server.

- $\quad$ Fungsi Respon Server Terhadap Banyak SMS.

Setelah dipastikan server mampu merespon dan memproses 1 SMS request yang masuk dengan baik, kemudian dilakukan proses ujicoba dengan dua skema ujicoba diantaranya dengan pengiriman 3 SMS secara langsung dan 5 SMS secara langsung dengan menggunakan format SMS pendaftaran pelanggan baru.

Hasil dari ujicoba ini bisa diperhatikan pada tabel 3 untuk pengiriman 3 SMS secara langsung. Sementara untuk pengiriman 5 SMS secara langsung ditunjukkan pada tabel 4.

Tabel 3. 3 SMS Request yang dikirimkan secara langsung dan waktu eksekusi.

\begin{tabular}{|l|l|c|c|l|}
\hline No & $\begin{array}{l}\text { Nomor } \\
\text { Handphone }\end{array}$ & Dibalas & Tidak & $\begin{array}{l}\text { Wak } \\
\text { tu }\end{array}$ \\
\hline 1 & 6285755500490 & $\mathrm{v}$ & - & $\begin{array}{l}14 \\
\text { detik }\end{array}$ \\
\hline 2 & 628563441945 & $\mathrm{v}$ & - & $\begin{array}{l}16 \\
\text { detik }\end{array}$ \\
\hline 3 & 085646668990 & $\mathrm{v}$ & - & $\begin{array}{l}19 \\
\text { detik }\end{array}$ \\
\hline
\end{tabular}

Tabel 3 memperlihatkan data nomor handphone yang semuanya diasumsikan sebagainomor pelanggan. Dari pengujian terhadap pengiriman 3 SMS secara langsung didapatkan waktu balasan yang nampak pada kolom Waktu.

Tabel 4.5 SMS Request yang dikirimkan secara langsung dan waktu eksekusi.

\begin{tabular}{|l|l|c|c|c|}
\hline No & $\begin{array}{l}\text { Nomor } \\
\text { Handphone }\end{array}$ & Dibalas & Tidak & Waktu \\
\hline 1 & 6285755500490 & - & v & - \\
\hline 2 & 628563441945 & v & - & $\begin{array}{c}16 \\
\text { detik }\end{array}$ \\
\hline 3 & 085646668990 & v & - & $\begin{array}{c}18 \\
\text { detik }\end{array}$ \\
\hline 4 & 6285655614359 & v & - & $\begin{array}{c}20 \\
\text { detik }\end{array}$ \\
\hline 5 & 6285649633442 & v & - & $\begin{array}{c}23 \\
\text { detik }\end{array}$ \\
\hline
\end{tabular}

Nomor handphone yang tertera pada tabel 4 semuanya diasumsikan sebagai nomor handphone pelanggan. Dari hasil pengujian terhadap pengiriman 5 SMS tersebut didapatkan waktu balasan yang nampak pada kolom Waktu. Pada pengujian ini ada 1 pelanggan yang tidak mendapatkan respon dari server, untuk nomor yang tidak mendapatkan respon dari server bisa diperhatikan pada tabel 4 .

Ujicoba pengiriman SMS request tersebut dilakukan di cuaca cerah dan di daerah yang mempunyai signalcukup kuat.

Berdasarkan data yang didapatkan dari ujicoba tersebut Nampak jika tingkat keberhasilan server SMS Gateway dalam merespon 3 SMS request yang masuk sebesar $100 \%$, sementara untuk 5 SMS request yang masuk sebesar $80 \%$.

Setelah dilakukan analisa lebih lanjut, Ada kemungkinan faktor yang menyebabkan kegagalan server dalam merespon semua SMS yang masuk adalah :

1. Manajemen thread yang dipakai dalam aplikasi kurang maksimal,yaitupenanganan terhadap AT Command SMSlaporan yang masuk, dengan thread yang digunakan untuk memproses SMSbalasan. Kedua proses ini terjadi tabrakan ketika AT Command respon pengiriman SMS balasan dengan laporan pengiriman SMS terjadi secara bersamaansehingga terjadi tabrakan.

2. Perangkat handphone yang digunakan tidak disetting untuk tidak menerima laporan pengiriman SMS. Sehingga ketika menjalankan proses AT Command respon pengiriman dilakukan berbenturan dengan AT Command SMS laporan yang masuk.

\section{KESIMPULAN}

Berdasarkan data ujicoba dan analisa maka dapat ditarik kesimpulan:

1. Penelitian ini berhasil membuat sebuah Aplikasi SMS Gateway Sebagai Media Informasi Harga Barang Toko Margo Rukun Nganjuk.

2. Aplikasi SMS Gateway yang dibangun dapat memproses SMS request yang masuk dengan tingkat keberhasilan $100 \%$ untuk 3 SMS yang dikirimkan secar langsung. Sementara untuk 5 SMS request yang dikirimkan secara langsung server hanya bisa mempunyai tingkat keberhasilan sebesar $80 \%$. 


\section{DAFTAR PUSTAKA}

[1] Pramsane Saranphong, SanjayaRidwan. Mobile Education Services Based on SMS and Their Architecture Comparison. Third International Conference on eLearning for Knowledge-Based Society,Bangkok, Thailand, August 34, 2006.

[2] Sunardi, Murti Hari, Listiyono Hersatoto , Aplikasi SMS Gateway, Jurnal Teknologi Informasi DINAMIK, Semarang, 2009.

[3] Suryani ,Rancang Bangun Sistem Informasi Sekolah Via SMS Gateway Berbasis CMS , Skrispsi Sarjana pada UIN Malang , 2008 : Tidak Diterbitkan.
[4] Purnomo Adi, Pemrograman Java 2 , Membangun Beragam Aplikasi Layanan SMS, Salemba Infotek, Semarang, 2007.

[5] Hariyanto Bambang. Esensi-esensi Bahasa Pemrograman Java Informatika, 2005.

[6] Wahan Komputer, Buku Latihan membuat Aplikasi Profesional dengan Java, PT Gramedia, Jakarta,2005.

[7] RosenbergDoug and Stephens Matt ,Use Case Driven Object Modeling with UML, Apress, New Tork, 2007. 